$\begin{array}{ll}\text { Research Square } & \text { Preprints are preliminary reports that have not undergone peer review. } \\ \text { They should not be considered conclusive, used to inform clinical practice, } \\ \text { or referenced by the media as validated information. }\end{array}$

\title{
Yeasts are able to inhibit growth of disease-associated fungi
}

Enikố Horváth

Debreceni Egyetem

Matthias Sipiczki

Debreceni Egyetem

Hajnalka Csoma

Debreceni Egyetem

Ida Miklos ( $\nabla$ miklos.ida@science.unideb.hu )

Debreceni Egyetem

\section{Research article}

Keywords: disease-associated fungi, bioactive agents, yeast, Metschnikowia sp., Pichia sp., Candida sp., natural resistance.

Posted Date: December 5th, 2019

DOl: https://doi.org/10.21203/rs.2.18243/v1

License: (c) (i) This work is licensed under a Creative Commons Attribution 4.0 International License. Read Full License 


\section{Abstract}

Background Fungal sepsis is often caused by non-albicans Candida or other species. These disease-associated species have strong virulence and often show resistance to the commonly used antifungal treatments. Therefore, finding new inhibitory agents nowadays is increasingly urgent.

Results Our screening revealed that although the pathogenic fungi were much more tolerant to yeast-produced bioactive agents than the non-diseaseassociated yeasts, growth of Kodamaea ohmeri and Candida tropicalis could be inhibited by Metschnikowia andauensis, while Cryptococcus albidus can be controlled by Pichia anomala and Candida tropicalis. The size of the inhibitory zone formed by yeasts was depended on media, $\mathrm{pH}$ and temperature. However, extensive studies were carried out, we failed to find inhibitory yeast against Pichia kudriavzevii, suggesting that it must have high natural resistance.

Conclusions Certain yeast species can contribute to the future solutions of problems caused by fungal resistance and can be good candidates for finding new bioactive agents which inhibit growth of disease-associated fungi.

\section{Background}

Fungaemia is associated with substantial morbidity and mortality of immuno-compromised persons. Studies have demonstrated that fungal sepsis can quite often be caused by non- albicans Candida species. Pichia kudriavzevii (is the teleomorph of the Candida krusei). was isolated from neonates and hospitalized patients [1,2, reviewed in 3]. It is supposed to be the fifth most common cause of candidemia. Kodamaea ohmeri cells (is the teleomorph of Candida guillermondii). were isolated from infant and neonate or wound lesions and blood in several cases [reviewed in 3 and 4, 5, 6]. Candida tropicalis is one of the most common colonizer in tropical countries. Its infections involve gastrointestinal invasions or arthritis [reviewed in 7], while Cryptococcus albidus was isolated from transplant recipient and lesion $[8,9]$.

Successful infection of the mentioned above species can be in connection with their dimorphisms (ability to morphological switch), polymorphisms of their virulence-related genes and possibly with their resistance to the commonly used antifungal agents $[5,10,11,12,13,14]$.

Because of these problems, we wanted to investigate whether cell division of the disease-associated species mentioned above can be inhibited by bioactive agents produced by yeasts or not. Well-known antagonistic species and species not studied for biological control were equally tested. Our screening revealed the species that were able to inhibit cell division of infectious fungi and shed light on that size of the inhibitory zones produced by the yeasts, strongly depended on media, $\mathrm{pH}$ and temperature. Our data suggested that Pichia kudriavzevii must have strong inherited resistance to the yeast-produced antifungal agents.

\section{Results}

\section{Metschnikowia andauensis, Pichia anomala, Candida tropicalis were able to inhibit growth of disease-associated fungi}

In order to find yeast species which are able to inhibit cell division of the disease-associated species, such as Pichia kudriavzevii, Kodamaea ohmeri, Candida tropicalis, Cryptococcus albidus [1, 2, 3, 4, 5, 6, 7, 8], several yeasts were investigated. The test yeast strains were divided into two groups. Species with known biocontrol capacity, such as Pichia anomala, Metschnikowia species, Saccharomyces cerevisiae belonged to the first group [10, 17, 18, 19, 20, 21 and in review 22]. Members of the second test group (Candida stigmatis, Hanseniaspora thailandica, Candida ethanolica, Pichia dorogensis, Cryptococcus flavescens, Candida verbasci, Wickerhamomyces orientalis) were randomly selected from those yeasts whose biocontrol capacity were not earlier investigated.

As the Table 1 shows, growth of Kodamaea ohmeri (11-466) (Fig.1a) and Candida tropicalis (11-471) could be inhibited by M. andauensis cells (11-1120), while Cryptococcus albidus (2-1365) was controlled by P. anomala (11-502) and C. tropicalis (11-476). Other test species were not able to form inhibitory zone on the lawns of disease-associated species, in turn they were effective in the case of non-disease-associated yeast lawns, which were used as control (Table 1). Among the non-disease-related species, the Saccharomycopsis crataegensis (11-463) and Wickerhamomyces orientalis (11-461) cells were especially sensitive, because almost all test strains were able to inhibit their growth (Table 1). Interestingly, in some cases, growth stimulation around of the lawn (indicated with S in the Table 1, Fig.1b) or co-occurence of inhibitory- and stimulation zones could also be observed (indicated with I-S in the Table 1, Fig.1c).

\section{Pichia kudriavzevii was highly resistant}

Our screening suggested that Pichia kudriavzevii (11-462, 11-460) can have strong resistance against yeasts (Table 1). To learn whether it is true or not, further test strains belonging to different species and originated from different regions of the World were investigated on the Pichia kudriavzevii (11-460, 11-462) lawns. Our data confirmed the strong resistance of Pichia kudriavzevii (Table 2), since altogether 50 strains belonging 35 species were not able to inhibit its growth on complete and minimal media (Table 2). In contrast, Saccharomycopsis crataegensis cells (11-463) (used as control) could be inhibited by several yeast species (Table 2).

\section{Size of inhibitory zone can strongly depend on media, $\mathrm{pH}$ and temperature}

Our earlier data suggested that medium and culture conditions can have strong impact on biocontrol activity (see Saccharomycopsis crataegensis-Table 2). Thus, we repeated our experiments with one of the disease-associated species (Cryptococcus albidus) (2-1365) applying minimal (EMMA) and complete (YPA) media, different $\mathrm{pH}$ and temperature and using further test strains. Our data confirmed that culture conditions can strongly influence antagonistic effect of the test strains (Table 3). Consequently, modifying of the culture conditions could lead to finding further antagonistic species, such as e.g. Candida insectorum (11-1193) against Cryptococcus albidus (Table 3). 


\section{Discussion}

Non-albicans Candida or other species including Pichia kudriavzevii, Kodamaea ohmeri Candida tropicalis or Cryptococcus albidus have been more frequently isolated from hospitalized patients $[1,2,3,4,7,9]$. These species seem to be very virulent and often show resistance to the commonly used antifungal treatments $[5,7,13,14]$. Thus, consequences of these fungal infections can be very serious, especially in children, neonates or immune-compromised patients. Accordingly, finding new inhibitory agents is increasingly urgent.

In order to identify yeast species which can have inhibitory effect against disease-associated fungi, screening of yeasts on Pichia kudriavzevii, Kodamaea ohmeri, Candida tropicalis, Cryptococcus albidus lawns were carried out. Our data showed that growth of Kodamaea ohmeri and Candida tropicalis could be inhibited by Metschnikowia andauensis, while Cryptococcus albidus can be controlled by Pichia anomala and Candida tropicalis (Table 1, Fig.1a). It means that bioactive agents of these inhibitory test strains well worth examining and yeasts can be attractive possibilities in the future solution of fungal resistance problems. Although, certain enzymes and proteins produced by these yeasts are partly known $(11,17,23,24,25)$, we do not know exactly, which inhibitory agent was effective against the disease-associated strains mentioned above. To identify them precisely, further studies are required. Our tests shed also light that pathogenic fungi are much more tolerant to bioactive agents than the non-disease-associated yeast, such as e.g. Saccharomycopsis crataegensis and Wickerhamomyces orientalis (Table 1). The antagonistic effects were often dependent on media, $\mathrm{pH}$ and temperature (Table 3), similarly to others observations obtained in different species $[26,27,28,29]$. The influencing factors could be species specific and their identification can lead to finding new inhibitory yeasts. Consequently, tests carried out under different culture conditions were very useful, since thereby further inhibitory yeasts (Pichia dorogensis, Wickerhamomyces orientalis, Trichosporon asahii, Sporidiobolus ruineniae, Candida insectorum) could be identified against Cryptococcus albidus (Table 3). In contrast, application of minimal and complex media and 50 different test strains (belonging to 35 species) did not lead to success in the case of Pichia kudriavzevii, because we failed to find inhibitory yeast against it (Table 2). Causes of its high resistance are not known and require further studies. We suppose that it can be an inherited species-specific feature of Pichia kudriavzevii, because our strains (11-460, 11-462) were isolated from nature and did not meet earlier with antifungal medicaments. Its high tolerance is in good agreement with multidrug resistance of the clinical isolates [2].

Our experiments shed also light on complexity of the action of bioactive agents, since growth stimulation was noticed in certain lawns (Fig.1 b) (Tables 1, 3), similarly to the previous experiences [28,30]. Co-appearance of inhibitory- and stimulation zones was more interesting and unexpected (Fig. $1 \mathrm{c}$ ). The latter phenomenon suggests a sophisticated mechanism of action and can indicate that effect of the bioactive agent produced by $M$. andauensis might be concentration dependent.

\section{Conclusion}

Taken together, this study demonstrates that yeasts can be good candidates for finding new bioactive agents which can inhibit growth of disease-associated fungi. These bioactive agents can contribute to the future solutions of problems of fungal resistance.

\section{Materials And Methods}

\section{Strains}

Strains used in this study were purchased from collections (Metschnikowia andauensis (11-1120) HA 1657, Metschnikowia pulcherrima 11-11 CBS 610, Metschnikowia pulcherrima 11-578 CBS 5833) or collected by Prof. Sipiczki from different regions of the World (Table 2).

\section{Taxonomic position}

PCR and sequencing methods were used for identification of the strains. Taxonomic position of the yeast species were identified by analysis of D1/D2 domain of 26S rDNA [15] (Table 2).

\section{Culture media}

Yeast strains were grown in YPL (1\% yeast extract, $2 \%$ glucose, $2 \%$ peptone), YPA (YPL+2.5\% agar) and EMMA [16].

\section{Spot assay for growth inhibition}

Cells of the overnight culture (YPL incubated at $28^{\circ} \mathrm{C}$ ) were harvested and cell suspension was prepared in sterile water (final cell density was $\mathrm{OD}_{595}=1$ ). EMMA minimal and YPA complete media were flooded with $1 \mathrm{~mL}$ of the cell suspension. After drying of the cell suspension in sterile box (lawn), yeast strains to be tested for antagonistic capacity (test-strain) were streaked or dropped ( $10 \mathrm{ul}$ of cell suspension, $\mathrm{OD}_{595}=1$ ) onto the surface of agar plates and were incubated at the indicated temperature. Appearances of inhibitory zones were investigated after 3-10 days. The results are coming from three separate experiments.

\section{Declarations}

\section{Ethics approval and consent to participate}

Not applicable.

\section{Consent for publication}


Not applicable.

\section{Availability of data and materials}

Data of this study are included in this published article.

\section{Competing of interest}

The authors declare no conflict of interest.

\section{Funding}

This study was supported by the European Union and the European Social Fund through EFOP-3.6.1-16-2016-00022 and FIK 20428-3/2018 projects. Authors' contributionsHE: performed the experiments and participated in study design. MS: collected the strains and determined the taxonomic positions of the strains. HCs: participated in the spot-assays and data analysis. MI: study design, data analysis and writing the manuscript.

\section{Acknowledgements}

We thank llona Lakatos for technical assistance.

\section{References}

1. Nagarathnamma T, Chunchanur SK, Rudramurthy SM, Vineetha KR, Ramamurthy K, Joseph J, Ambica R. Outbreak of Pichia kudriavzevii fungaemia in a neonatal intensive care unit. J Med. Microbiol. 2017; 66(12):1759-1764.

2. Pfaller MA, Diekema DJ, Gibbs DL, Newell VA, Nagy E, Dobiasova S, Rinaldi M, Barton R, Veselov A. Global Antifungal Surveillance Group. Candida krusei, a multidrug-resistant opportunistic fungal pathogen: geographic and temporal trends from the ARTEMIS DISK Antifungal Surveillance Program, 2001 to 2005 . J Clin. Microbiol. 2008; 46(2):515-21.

3. Ayaka T, Nei T, Sugimoto R, Watanabe A, Hagiwara J, Takiguchi T, Yokota H, Kamei K. Kodamaea ohmeri fungemia in severe burn: Case study and literature review. Med. Mycol. Case Rep. 2018; 22: 21-23.

4. Vivas R, Beltran C, Munera MI, Trujillo M, Restrepo A, Garcés C. Fungemia due to Kodamaea ohmeri in a young infan and review of the literature. Med. Mycol. Case Rep. 2016; 13: 5-8.

5. Yang BH, Peng MY, Hou SJ, Sun JR, Lee SY, Lu JJ. Fluconazole-resistant Kodamaea ohmeri fungemia associated with cellulitis: Case report and review of the literature. Int. J. Infect. Dis. 2009;13(6):e493-7.

6. Al-Sweih N, Khan ZU, Ahmad S, Devarajan L, Khan S, Joseph L, Chandy R. Kodamaea ohmeri as an emerging pathogen: a case report and review of the literature. Med Mycol. 2011; 49(7):766-70.

7. Kothavade RJ, Kura MM, Valand AG, Panthaki MH. Candida tropicalis: its prevalence, pathogenicity and increasing resistance to fluconazole. J. Med. Microbiol. 2010; 59(Pt 8):873-80.

8. Lee YA, Kim HJ, Lee TW, Kim MJ, Lee MH, Lee JH, Ihm CG. First Report of Cryptococcus albidus-induced disseminated Cryptococcosis in a renal transplant recipient. Korean J. Intern. Med. 2004; 19(1): 53-57.

9. Gharehbolagh SA, Nasimi M, Agha Kuchak Afshari S, Ghasemi Z, and Rezaie S. First case of superficial infection due to Naganishia albida (formerly Cryptococcus albidus) in Iran: A review of the literature. Curr. Med. Mycol. 2017; 3(2): 33-37.

10. Mengshan C, Li G, Liu Y, Liu G, Li M, Zhang X, Sun Z, Sui Y, Liu J. Increase in antioxidant enzyme activity, stress tolerance and biocontrol efficacy of Pichia kudriavzevii with the transition from a yeast-like to biofilm morphology. Biol. Control. 2015; 90: 113-119.

11. Negri M, Martins M, Henriques M, Svidzinski TI, Azeredo J, Oliveira R. Examination of potential virulence factors of Candida tropicalis clinical isolates from hospitalized patients. Mycopathologia. 2010; 169(3):175-82.

12. Zhang LJ, Yu SB, Li WG, Zhang WZ, Wu Y, Lu JX. Polymorphism analysis of virulence-related genes among Candida tropicalis isolates. Chin. Med. J. 2019;132(4):446-453.

13. Pelletier R, Alarie I, Lagacé R, Walsh TJ. Emergence of disseminated candidiasis caused by Candida krusei during treatment with caspofungin: Case report and review of literature. Med Mycol. 2005; 43(6):559-64.

14. Cordeiro Rde A, de Oliveira JS, Castelo-Branco Dde S, Teixeira CE, Marques FJ, Bittencourt PV, Carvalho VL, Bandeira Tde J, Brilhante RS, Moreira JL, Pereira-Neto Wde A, Sidrim JJ, Rocha MF. Candida tropicalis isolates obtained from veterinary sources show resistance to azoles and produce virulence factors. Med. Mycol. 2015; 1;53(2):145-52.

15. O'Donell K. Fusarium and its near relatives. The Fungal Holomorph: Mitotic, Meiotic and Pleomorphic Speciation in Fungal Systematics. (Reynolds DR \& Taylor JW, eds). CAB International, Wallingford, UK.1993; pp. 225-233.

16. Moreno S, Klar A, Nurse P. Molecular genetic analysis of the fission yeast Schizosaccharomyces pombe. Methods Enzymol. 1991; 194:795-823.

17. Manso T, Nunes C. Metschnikowia andauensis as a new biocontrol agent of fruit postharvest diseases. Postharvest Biol. and Technol. 2011; 61(1):64-71. 18. Bleve G, Grieco F, Cozzi G, Logrieco A, Visconti A. Isolation of epiphytic yeasts with potential for biocontrol of Aspergillus carbonarius and A. niger on grape. Int. J. Food Microbiol. 2006; 108(2):204-9.

19. Korres AM, Buss DS, Ventura JA, Fernandes PM. Candida krusei and Kloeckera apis inhibit the causal agent of pineapple fusariosis, Fusarium guttiforme. Fungal Biol. 2011; 115(12):1251-8.

20. Zhimo VY, Dilip D, Sten J, Ravat VK, Bhutia DD, Panja B, Saha J. Antagonistic yeasts for biocontrol of the banana postharvest anthracnose pathogen Colletotrichum musae. J. Phytopathol. 2017; 165:35-43.

21. Zeinat K, and Nermin Housam Abd El-Moniem NHA. Potential of antagonistic yeast strains as biocontrol agents against root rot disease in tomato. Int. J. 
Adv. Res. 2013; 1 (9): 372-390.

22. Sharma RR, Singh D, Singh R. Biological control of postharvest diseases of fruits and vegetables by microbial antagonists: A review. Biol. Control. 2009; 50(3):205-221.

23. Jijakli MH, Lepoivre P. Characterization of an exo-beta-1,3-glucanase produced by Pichia anomala strain $\mathrm{K}$, antagonist of Botrytis cinerea on apples.

Phytopathology. 1998; 88(4): 335-343.

24. Galán-Ladero MA, Blanco MT, Sacristán B, Fernández-Calderón MC, Pérez-Giraldo C, Gómez-García AC. Enzymatic activities of Candida tropicalis isolated from hospitalized patients. Med. Mycol. 2010; 48: 207-210.

25. Bajaj BK, Raina S, Singh S. Killer toxin from a novel killer yeast Pichia kudriavzevii RY55 with idiosyncratic antibacterial activity. J. of Basic Microbiology. 2013; 53(8): 645-656.

26. Raspor P, Miklic-Milek D, Avbelj M, Cadez N. Biocontrol of B. cinerea with wine yeasts, biocontrol of grey mould disease on grape caused by Botrytis cinerea with autochthonous wine yeasts. Food Technol. Biotechnol. 2010; 48(3):336-343. ISSN 1330-9862

27. Spadaro D, Ciavorella A, Dianpeng Z, Garibaldi A, Gullino ML. Effect of culture media and pH on the biomass production and biocontrol efficacy of a Metschnikowia pulcherrima strain to be used as a biofungicide for postharvest disease control. Can. J. Microbiol. 2010; 56(2): $128-37$.

28. Sipiczki M. Metschnikowia strains isolated from botrytized grapes antagonize fungal and bacterial growth by iron depletion. Appl and Environ. Microbiol. 2006; 72(10): 6716-6724.

29. Dabrowska IV, Tkachenko KS, Podgorsky VS, Fomina MO. Anti-Staphylococci activity of yeast isolates affected by pH of experimental medium. Фaktopй ekcnerùmehtalıhoï opґgahişmib. 2015; 179-182. ISSN 2219-3782

30. Sipiczki M. Overwintering of Vineyard Yeasts: Survival of Interacting Yeast Communities in Grapes Mummified on Vines. Front. Microbiol. $2016 ; 7: 212$.

\section{Tables}

Table 1. Yeast species are able to inhibit growth of disease-associated fungi.

\begin{tabular}{|c|c|c|c|c|c|c|c|c|}
\hline \multirow{3}{*}{$\begin{array}{l}\text { Collection } \\
\text { number }\end{array}$} & \multirow{3}{*}{$\begin{array}{l}\text { Test-strains } \\
\text { Species } \\
\text { with known } \\
\text { biocontrol } \\
\text { capacity }\end{array}$} & \multicolumn{4}{|c|}{$\begin{array}{l}\text { Lawn } \\
\text { diseases-associated species }\end{array}$} & \multicolumn{3}{|c|}{$\begin{array}{l}\text { Lawn } \\
\text { non-disease-related species }\end{array}$} \\
\hline & & $11-462$ & $11-466$ & $11-471$ & $2-1365$ & $11-465$ & $11-463$ & $11-467$ \\
\hline & & $\begin{array}{l}\text { Pichia } \\
\text { kudriavzevii/** }\end{array}$ & $\begin{array}{l}\text { Kodamaea } \\
\text { ohmeri }\end{array}$ & $\begin{array}{l}\text { Candida } \\
\text { tropicalis }\end{array}$ & $\begin{array}{l}\text { Cryptococcus } \\
\text { albidus }\end{array}$ & $\begin{array}{l}\text { Candida } \\
\text { stigmatis }\end{array}$ & Saccharomycopsis crataegensis & $\begin{array}{l}\text { Starmert } \\
\text { melipon }\end{array}$ \\
\hline $11-460$ & Pichia kudriavzevii & - & - & - & - & - & + & - \\
\hline $11-502$ & Pichia anomala & - & - & - & + & + & + & - \\
\hline $11-481$ & $\begin{array}{l}\text { Saccharomyces } \\
\text { cerevisiae }\end{array}$ & - & - & - & S & - & + & nd \\
\hline $11-476$ & Candida tropicalis & - & - & - & + & - & + & - \\
\hline $11-1120$ & $\begin{array}{l}\text { Metschnikowia } \\
\text { andauensis }\end{array}$ & - & + & + & - & + & I-S & + \\
\hline $11-578$ & $\begin{array}{l}\text { Metschnikowia } \\
\text { pulcherrima }\end{array}$ & - & - & - & $\mathrm{S}$ & + & S & + \\
\hline \multirow[t]{2}{*}{$11-11$} & $\begin{array}{l}\text { Metschnikowia } \\
\text { pulcherrima }\end{array}$ & - & - & - & $\mathrm{S}$ & + & S & - \\
\hline & $\begin{array}{l}\text { species with no } \\
\text { known biocontrol } \\
\text { capacity }\end{array}$ & & & & & & & \\
\hline $11-465$ & Candida stigmatis & - & - & - & - & - & + & - \\
\hline $11-472$ & $\begin{array}{l}\text { Hanseniaspora } \\
\text { thailandica }\end{array}$ & - & - & - & $\mathrm{S}$ & - & + & - \\
\hline $11-486$ & Pichia dorogensis & - & - & - & - & - & + & - \\
\hline $11-489$ & $\begin{array}{l}\text { Cryptococcus } \\
\text { flavescens }\end{array}$ & - & - & - & - & - & + & - \\
\hline $11-1055$ & Candida verbasci & - & - & - & - & - & + & + \\
\hline $11-461$ & $\begin{array}{l}\text { Wickerhamomyces } \\
\text { orientalis }\end{array}$ & - & - & - & - & S & - & + \\
\hline
\end{tabular}


-:no inhibitory zone on EMMA $(\mathrm{pH} 7)$ at room temperature

+: appearance of inhibitory zone on EMMA $(\mathrm{pH})$ at room temperature

S: growth stimulation

I-S: co-occurence of inhibitory- and stimulation zone

nd: not determined

**11-460 strain used as lawn gave the same results

Table 2 Pichia. kudriavzevii has strong resistance against yeast-produced bioactive agents.

Petri dishes were generally incubated at room temperature (RT)

+ : there was inhibitory zone

-: no inhibitory zone

1:11-462 Pichia kudriavzevii strain and complete media gave similar result

2:11-460 and 11-462 were isolated from Sri Lanka, Colombo

** This species has not yet been identified. Analysis of the D1/D2 domain of its 26S ribosomal DNA suggests close relation with Pichia minuta. GenBank Accession number: JX515967.1

Table 3 Composition of the media, pH and temperature can influence inhibition of Cryptococcus albidus

\author{
- : no inhibitory zone \\ +: appearance of the inhibitory zone \\ nd : not determined,
}

S: stimulation

I-S: co-occurence of inhibitory- and stimulation zone

\title{
Figures
}

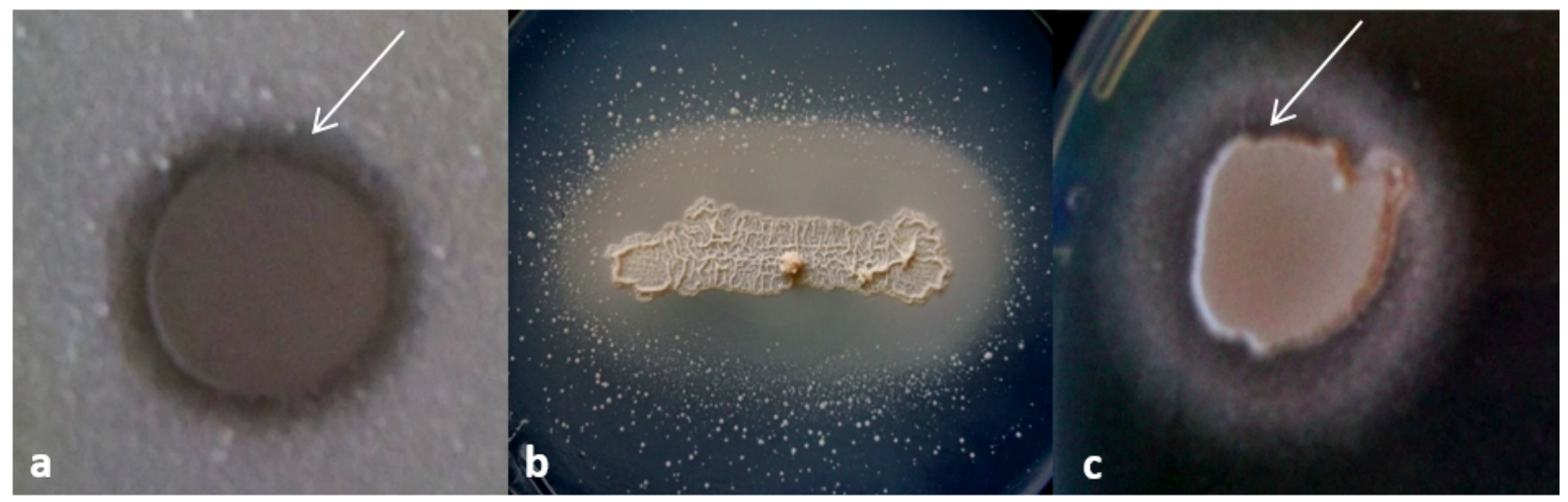

\section{Figure 1}

Yeast-produced bioactive agents can cause not only inhibition, but growth stimulation. (a) Inhibition - lawn: Kodamae ohmeri (11-466), test strain: Metschnikowia andauensis (11-1120) (C. tropicalis lawn gave similar result). (b) Growth stimulation - lawn: Candida diversa (11-470), test strain: Candida tropicalis (11-476). Co-occurence of inhibitory and stimulation zones could also be observed (c) lawn: Saccharomycopsis crataegensis (11-463), test strain: Metschnikowia andauensis (11-1120). EMMA media pH6.5 were incubated at room temperature and photographed after 5 days. White arrows show the clear inhibitory zone, where cells of the lawn could not divide. 


\begin{tabular}{|c|c|c|c|c|}
\hline $\begin{array}{l}\text { Collection } \\
\text { number }\end{array}$ & Test-strain & Test-strain & $\begin{array}{c}\text { Lawn 11-460 } \\
\text { Pichia } \\
\text { kudriavzevii }\end{array}$ & $\begin{array}{c}\text { Lawn 11-463 } \\
\text { Saccharomycopsis crataegensis }\end{array}$ \\
\hline & Species & Origin & \multicolumn{2}{|c|}{ Growth inhibition } \\
\hline & & & \multicolumn{2}{|r|}{ Media } \\
\hline & & & EMMA & EMMA/YPA \\
\hline $11-483$ & $\begin{array}{l}\text { New species similar to Pichia } \\
\text { minuta ** }\end{array}$ & Borneo, Brunei & - & - \\
\hline $11-503$ & Pichia anomala & $\begin{array}{l}\text { Laos, Luang } \\
\text { Prabang }\end{array}$ & - & $-1+$ \\
\hline $11-520$ & Pichia anomala & Laos, Vientiane & - & $-1+$ \\
\hline $11-522$ & Pichia anomala & Laos, Vientiane & - & $-1+$ \\
\hline $11-485$ & Pichia bruneiensis & Borneo, Brunei & - & $-1+$ \\
\hline $11-480$ & Pichia manshurica & Philippines, Manila & - & $+1-$ \\
\hline $11-461$ & Wickerhamomyces orientalis & Sri Lanka, Galle & - & - \\
\hline $11-496$ & Saccharomycopsis crataegensis & Philippines, Manila & - & - \\
\hline $11-464$ & Metschnikowia koreensis & India, Hyderabad & - & - \\
\hline $11-482$ & Metschnikowia koreensis & Borneo, Brunei & - & $-1+$ \\
\hline $11-524$ & Metschnikowia laotica & $\begin{array}{l}\text { Laos, Luang } \\
\text { Prabang }\end{array}$ & - & $-1+$ \\
\hline $11-1062$ & Metschnikowia pulcherrima & Georgia, Tbilisi & - & $-1+$ \\
\hline $11-523$ & Candida glabrata & Laos, Vientiane & - & $+1-$ \\
\hline $11-484$ & Candida boidinii & Borneo, Brunei & - & - \\
\hline $11-471$ & Candida tropicalis & Philippines, Caticlan & - & - \\
\hline $11-521$ & Candida tropicalis & Laos, Vientiane & - & $-1+$ \\
\hline $11-470$ & Candida diversa & Borneo, Brunei & - & $+1-$ \\
\hline $11-477$ & Candida californica & Borneo, Brunei & - & - \\
\hline $11-478$ & Candida californica & Borneo, Brunei & - & - \\
\hline $11-473$ & Candida ethanolica & Borneo, Brunei & - & - \\
\hline $11-469$ & Candida citri & Borneo, Brunei & - & $-1+$ \\
\hline $11-488$ & Candida pseudointermedia & Borneo, Brunei & - & $-1+$ \\
\hline $11-479$ & Candida zemplinina & Philippines, Manila & - & - \\
\hline $11-487$ & Candida borneonana & Borneo, Brunei & - & - \\
\hline $11-504$ & Candida intermedia & $\begin{array}{c}\text { Laos, Luang } \\
\text { Prabang }\end{array}$ & - & $-1+$ \\
\hline $11-506$ & Candida jaroonii & $\begin{array}{c}\text { Laos, Luang } \\
\text { Prabang }\end{array}$ & - & $-/+$ \\
\hline $11-512$ & Candida jaroonii & $\begin{array}{l}\text { Laos, Luang } \\
\text { Prabang }\end{array}$ & - & $-1+$ \\
\hline $11-514$ & Candida jaroonii & $\begin{array}{l}\text { Laos, Luang } \\
\text { Prabang }\end{array}$ & - & $-1+$ \\
\hline $11-507$ & Candida suratensis & $\begin{array}{l}\text { Laos, Luang } \\
\text { Prabang }\end{array}$ & - & $-1+$ \\
\hline $11-509$ & Candida suratensis & $\begin{array}{l}\text { Laos, Luang } \\
\text { Prabang }\end{array}$ & - & $-1+$ \\
\hline $11-510$ & Candida suratensis & $\begin{array}{l}\text { Laos, Luang } \\
\text { Prabang }\end{array}$ & - & $-1+$ \\
\hline $11-513$ & Candida butyri & $\begin{array}{l}\text { Laos, Luang } \\
\text { Prabang }\end{array}$ & - & - \\
\hline $11-517$ & Candida sergipensis & Laos, Vientiane & - & $+1-$ \\
\hline $11-519$ & Candida parapsilosis & Laos, Vientiane & - & - \\
\hline $11-466$ & Kodamaea ohmeri & India, Hyderabad & - & $-1+$ \\
\hline $11-490$ & Kodamaea ohmeri & Philippines, Manila & - & $-1+$ \\
\hline $11-500$ & Kodamaea ohmeri & Philippines, Manila & - & $-1+$ \\
\hline $11-467$ & Starmerella meliponinorum & India Hyderabad & - & + \\
\hline $11-1071$ & Starmerella caucasica & Azerbaijan, Baku & - & + \\
\hline $11-474$ & Torulaspora delbrueckii & Borneo, Brunei & - & $+1-$ \\
\hline $11-475$ & Issatchenkia terricola & Borneo, Brunei & - & - \\
\hline $11-491$ & Hanseniaspora thailandica & Philippines, Manila & - & - \\
\hline $11-495$ & Hanseniaspora thailandica & Philippines, Manila & - & - \\
\hline $11-499$ & Hanseniaspora thailandica & Philippines, Manila & - & - \\
\hline $11-494$ & Hanseniaspora uvarum & Philippines, Manila & - & - \\
\hline $11-501$ & Aureobasidium pullulans & Philippines, Manila & - & $-1+$ \\
\hline $11-511$ & Metahyphopichia laotica & $\begin{array}{l}\text { Laos, Luang } \\
\text { Prabang }\end{array}$ & - & - \\
\hline $11-516$ & Metahyphopichia laotica & Laos, Vientiane & - & $-1+$ \\
\hline $11-518$ & Cryptococcus heveanensis & Laos, Vientiane & - & - \\
\hline $11-489$ & Cryptococcus flavescens & Philippines, Banaue & - & + \\
\hline
\end{tabular}




\begin{tabular}{|c|c|c|c|c|c|c|c|c|c|}
\hline \multicolumn{2}{|r|}{ Test-strains } & \multicolumn{8}{|c|}{ Lawn: 2-1365 Cryptococcus albidus } \\
\hline Collection number & Species & $\begin{array}{c}\mathrm{pH}=5 \mathrm{YPA} \\
24^{\circ} \mathrm{C}\end{array}$ & $\begin{array}{c}\mathrm{pH}=6.5 \mathrm{YPA} \\
24^{\circ} \mathrm{C}\end{array}$ & $\begin{array}{c}\mathrm{pH}=5 \\
\mathrm{EMMA} \\
24^{\circ} \mathrm{C}\end{array}$ & $\begin{array}{c}\mathrm{pH}=6.5 \\
\mathrm{EMMA} \\
24^{\circ} \mathrm{C}\end{array}$ & $\begin{array}{c}\mathrm{pH}=5 \\
\mathrm{YPA} \\
30^{\circ} \mathrm{C} \\
\end{array}$ & $\begin{array}{c}\mathrm{pH}=6.5 \mathrm{YPA} \\
30^{\circ} \mathrm{C}\end{array}$ & $\begin{array}{c}\mathrm{pH}=5 \\
\mathrm{EMMA} \\
30^{\circ} \mathrm{C}\end{array}$ & $\begin{array}{c}\mathrm{pH}=6.5 \\
\mathrm{EMMA} \\
30^{\circ} \mathrm{C}\end{array}$ \\
\hline $11-460$ & Pichia kudriavzevii & - & - & - & - & - & - & + & - \\
\hline $11-1146$ & Pichia kudriavzevii & - & - & - & - & - & - & + & - \\
\hline $11-502$ & Pichia anomala & + & + & - & + & + & + & - & + \\
\hline $11-481$ & Saccharomyces cerevisiae & - & - & - & $\mathrm{S}$ & - & - & + & - \\
\hline $11-476$ & Candida tropicalis & + & + & - & + & + & + & - & + \\
\hline $11-505$ & Pichia guilliermondi & - & - & - & - & - & - & - & - \\
\hline $11-1120$ & Metschnikowia andauensis & - & - & $\mathrm{I}-\mathrm{S}$ & - & + & - & + & - \\
\hline $11-578$ & Metschnikowia pulcherrima & - & - & $\mathrm{S}$ & - & - & - & $\mathrm{S}$ & - \\
\hline $11-11$ & Metschnikowia pulcherrima & - & - & $\mathrm{S}$ & $\mathrm{S}$ & & - & $\mathrm{S}$ & - \\
\hline $11-465$ & Candida stigmatis & - & - & - & - & - & - & - & - \\
\hline $11-472$ & Hanseniaspora thailandica & - & - & - & $\mathrm{S}$ & - & - & - & - \\
\hline $11-473$ & Candida ethanolica & - & - & - & - & - & - & - & - \\
\hline $11-486$ & Pichia dorogensis & + & - & + & - & + & - & + & - \\
\hline $11-489$ & Cryptococcus flavescens & - & - & - & - & - & - & - & - \\
\hline $11-1055$ & Candida verbasci & - & - & - & - & - & - & - & - \\
\hline $11-461$ & Wickerhamomyces orientalis & + & + & - & - & - & - & - & - \\
\hline $11-523$ & Candida glabrata & - & - & - & - & - & - & - & - \\
\hline $11-1127$ & Trichosporon asahii & - & - & + & + & - & - & + & + \\
\hline $11-1135$ & Pichia kluyveri & - & - & - & - & - & - & - & - \\
\hline $11-1185$ & Sporidiobolus ruineniae & + & + & - & - & + & + & - & $\mathrm{S}$ \\
\hline $11-1193$ & Candida insectorum & + & + & + & + & + & + & + & + \\
\hline $2-1366$ & Candida magnifica & - & - & - & - & - & - & - & - \\
\hline
\end{tabular}

